\title{
An Inquiry into the Role of Women in Pre- Ahom and Ahom Society with Special Focus on the Institution of Kamakhya
}

\author{
NILAM KAKATI
}

Department of History, University of Hyderabad, Hyderabad, India.

\begin{abstract}
The role of women in Pre- Ahom and Ahom society could be regarded in the broader environment within the ambit of sacred space dedicated to them. Kamakhya temple, situated near Guwahati, Assam is the most profound illustration of the sacred space of women. It is celebrated as one of the renowned centres of Tantra in India in general and Assam in particular. It has established itself not only as an eminent Tantric centre but also as a menstruating Goddess. However, menstruation has been treated as a taboo since the earliest times in various religious texts. It represented the image of impurity and pollution and was dubbed as hot and dangerous. However, in Kamakhya temple, annual menstruation of the goddess is celebrated as a festival. In June every year, Ambubachi Mela represents one of the chief celebrations of the temple. The paper attempts to analyze the theme of menstruation, placing it in the border context of Kamakhya. The article also highlights the unrestricted movement of women in the pre- Ahom and Ahom society owing to its characteristics of the tribal bearing. The study claims that the inherent dichotomy of pure-impure, auspicious- inauspicious becomes unfitting in the case of Kamakhya and her annual menstruation festival. This specifics could pave the way to identify the theme of menstruation as a lone entity beyond the dichotomy which might aid in offering a fresh understanding of the same. The study employs the mixed methodology of hermeneutics and feminist theology.
\end{abstract}

\section{Introduction}

Assam, situated in the North- East of India, is a part of the historical narrative in association with the Tantric tradition. 'Assam has a reputation as a pre-eminent site for Shaktism, that is, for the worship of the goddess. Especially, we find the worship of the goddess in its Tantric forms. ${ }^{1}$ It has habitually been referred to as a dangerous and mystic land, which was surrounded by strange events like black magic, witchcraft and human sacrifice. Gait is of the view

\section{CONTACT Nilam Kakati 1 kakatinilam @ gmail.com 9 Department of History, University of Hyderabad, Hyderabad, India.}

\section{(c) (i)}

(C) 2020 The Author(s). Published by Enviro Research Publishers.

This is an $\partial$ Open Access article licensed under a Creative Commons license: Attribution 4.0 International (CC-BY).

Doi: http://dx.doi.org/10.12944/CRJSSH.3.2.15 
that 'The temple of Kamakhya at Guwahati is one of the most sacred shrines of the Shakti Hindus and the whole country is framed in Hindu traditions as a land of magic and witchcraft. ${ }^{2}$ However, it would be incorrect to deny Assam as a mystic and exotic land, but not dangerous. Aspects like tantric practices, the Kamakhya temple and Mayong, the land of magic have made ample contributions to categorize Assam as a mystic land.

The women question in Assam has been an issue of a query to scholars at various point of time. To grasp the comprehensive understanding of women question in the pre- Ahom and Ahom society, it has to be observed through the lens of sacred space, as it constituted one of the most vital elements in the socio-cultural setting. This paper will make an attempt to explore the bearing of women in sacred space of Assam, in addition to surveying the elements of continuity and change from the pre- Ahom to Ahom society. In the process, an illustration of the menstruation festival, i.e. Ambubachi Mela of Kamakhya will be studied. The study claims that the elementary dichotomy of pure-impure, auspicious-inauspicious bracketed around a mensuration woman and mensuration blood becomes unfitting in the case of Kamakhya and her annual mensuration festival. Thus the theme of mensuration could be grasped beyond the dichotomy as a lone entity which might offer a fresh understanding of the category irrespective from the understanding of the patriarchal notion.

\section{Methodology}

Mixed methodology of hermeneutics and feminist theology is employed for the composition of the study. Key texts on Tantra like Kalika Purana, Yogini Tantra, Yoni Tantra and Kamaratna Tantra are taken into account to comprehend the study of Hindu Tantra within the setting of hermeneutics. Eliade's frame of creative hermeneutics could be implemented to understand it better. The method of feminist theology is taken into account to comprehend the role of women in general and a menstruating women in particular in the various Indic religious traditions. Moreover, it can hardly be overlooked that the women question is one of the key features in the tantric tradition.

\section{Religious Bearing in pre-Ahom and Ahom society}

Pre Ahom Assam witnessed the elements of various attributes connected to socio-cultural settings. Sacred space encompassed elements of both tribal and Brahmanised aspects. The society comprised of non- Aryan and Aryan cultural elements. 'The settlement of Aryans in the kingdom appears to have begun earlier than the period of the Mahabharata war'3 Society was loosely based on the Varnasrama dharma. The king was determined with the duty to maintain the order. Brahmans occupied a higher position in society. They played a crucial role in transforming society. ${ }^{4}$

Inclusion of Brahmanised elements in the sacred space which was chiefly comprised of tribal beliefs was a process which led the embracement of both the traditions with the flexible and lenient approach. This flexible and sympathetic approach could be viewed as an enhancement not only in the socio-cultural space but also for women question, who could observe unrestricted movement. 'The Assamese society in the ancient days, as it has always been, was predominantly a non- Aryan society. In spite of its early intrusion, Aryan culture as such could not thrive in the land. Its transformation to adjust itself to the taste, temperament and religious beliefs and rites of the local people was perhaps greater in Assam than in other parts of India.... On the whole women enjoyed greater freedom from male- domination among certain sections of the people who were less under the Aryan influence or were non- Aryans. Besides, the non- Aryan attitude to women also had a positive impact on the Brahmanas who are noted to be more liberal than their counterparts elsewhere. ${ }^{5}$

The term Aryan and non- Aryan referred by Baruah can pose disagreement and debate, thus terms like Sanskritic and non- Sanskritic would also do justice in the state of the art understanding. However, the gist of the problem that can be grasped is that women's movement was not restricted as the societal norms were not rigid and harsh. ${ }^{5}$

Religious beliefs were allied with the female power of reproduction. This bracketing of religious beliefs and female also made an ample contribution in 
elevating the position of women. ${ }^{6}$ Religion was female worship centric. There was a belief that women were especially related to the Earth. Women actively took part in the religious ceremonies and were seen often as the liaison between man and the Gods.' Religious milieu grounded on women as a fundamental role motivated affirmative approach toward women.

With the coming of the Ahom, the process of inclusion in sacred space further augmented. Ahoms did not restrict the religious milieu to any certain tradition. 'Throughout the history of the Ahom monarchs, they never had a consistent religious policy. And accordingly, religious activities were determined more by the temperament of the kings and as to which sect or cult they patronized. ${ }^{7}$ Sacred space during the period was not the prerogative of any precise sect or tradition. 'Thus, Assam in the fifteenth century presented a picture of distinct religious and linguistic groups, the majority of whom were nonAryan. And those who professes Hinduism loosely adhered to Vaishnavism, Saivism and Shaktism or Tantrism. $^{8}$

Religious milieu during the pre- Ahom and Ahom society displays an image of inclusion and encompassment of both tribal and Brahmainsed aspect. The process continued progressively from the pre- Ahom to Ahom period, which further enhanced the same. Baruah argues that both the process of Sanskritization and Detribalization took place in pre- Ahom Assam. ${ }^{9}$

\section{Women Question in Pre- Ahom and Ahom Society}

Women question and religious bearing have an allied connotation during the said period. Flexibilities prevalent in the social status somewhat proved to be a boon for women. Their movements were not constrained as they could participate in agricultural activities. Reference of social evils like the practice of sati, purdah system and child marriage was not standard. Widow Remarriage was a norm in society. Social evils were not in fashion, which contributed to elevating the position of women than in the rest of the country. Baruah (1985), had dealt with the state of women in her work in length. 'Among the Mongoloid tribes, women had far greater freedom in marriage, divorce, and other matters than we find in orthodox Hindu society'. ${ }^{10}$

Lack of rigidity in the caste system has made an ample contribution to raising the position of women in society. Connotation of "caste" inaccurate and rigorous form could not be observed in the social context. It was amply grounded on the occupation and not practiced in a hereditary manner. 'In Assam, there seems to have been little or no distinction of castes from professions and each caste or tribe practiced all the arts which are known in the country. They were fanners, traders, blacksmiths, carpenters, extractors of oil, potters, weavers, dyers etc., but they had not the art of shaving, washing or bleaching, working in leather or of making sweetmeats, butter and ghee, ${ }^{11}$ 'People who practiced professions like weavers, potters or boatman also took to agriculture. Subhankarapataka plates of Dharmapala mentions of Orangi Tantras who were weavers by profession but also had land in their names. Similarly, the Suwalkuchi plates and the Puspabhadra plates mention lands owned by boatsmen and potters. ${ }^{12}$ Nonexistence is the rigidity of caste system also contributed towards nonexistence of vices allied with the same like the prescribed categories of marriages in sacred kinds of literature, control on the labor of women etc.

Observation on the women question regarding their unrestricted movement in societal status, participation in the agricultural process and lack of social evils could be made on circumstantial evidence. However, it cannot be overlooked that women had no equal share in land and property. The evidence could be viewed in the Nidhanpur Grant of Bhaskar Varman.

\section{Women Question and Sacred Space in Pre- Ahom and Ahom Society}

The bearing and understanding of women question could be realized in a flawless fashion when regarded from the lens of sacred spaces and the eminence of it. The theme of sacred allied with women highlighted the vigor of women in societal norm. The inscriptional reference could be observed which parallels queens with a goddess. Evidence like Nayanadevi, wife of Sthitavarman of Varnan dynasty, ${ }^{13}$ Srimangala, queen of Harjaravarman of Salastambha dynasty, ${ }^{14}$ 
Rajyadevi, wife of Indrapala of Pala dynasty ${ }^{15}$ was parallel to Goddess Lakshmi.

'Buranji', the Ahom historical chronicles dealt with political, economic and also social aspects, but it had scarce mention of women in its narratives. Elimination of women questions in the historical narrative was a bias till recently. The gap is, however, shrinking with writing, aiming to illustrate women as part and parcel of history. However, elimination of women in Buranji, the chief literary records of Ahoms can hardly be overlooked.

Women question and sacred space could be grasped evidently by exploring the institution of Kamakhya situated near Guwahati. Kamakhya is a renowned tantric centre has shared its prominence in the sacred space since the initiation. "From ancient times, Assam is known far and wide as a land of tantric faith, which is a primitive doctrine with a crude spiritual bias. It originated in the cult of blood and sacrificial rituals of the primitive tribes. The tantric faith is often described as a product of the vulgarized forms of Shaktism and the decadent phase of Buddhism. To put it in a more direct way, decadent Buddhism and the "nocturnal forces" of Shaktism coalesced and gave birth to the religion of Tantrism. The temple of Kamakhya was originally the progenitor of this cult and was vitally connected with the growth of its popularity. ${ }^{16}$ 'The name Kamakhya consists of three Austric words Ka Mai Kha. Ka means a sign of feminine gender, Mai means mother and Kha means to give birth, i.e. Kamakhya means the place where the mother gives birth or the sigh of mother's yoni through which she has given birth. ${ }^{17}$

Unrestricted movement of women relatively continued with time. It was enhanced further with their inclusion in the Tantric sect, which endorsed them to take identical part with the male counterpart. Tantric sacred space and environment encouraged them to partake in it. Women and Sudras had a secured position in the Tantric tradition, which was not common in Indic religious traditions. Tantra elevated the sacred space of female deities. Female could also play the role of guru or supreme teacher in the tradition. Kali, in her various forms, is reflected as a Shakti deity in the tradition. However, there exists a dual side to it, which is represented by both Shiva and Shakti. 'Another significant facet of
Tantric tradition is that in its practices, female deities are placed on a higher platform then the male deity. Like, in contrast to Siva, Shakti, his consort takes a prominent position. Woman in Tantra is venerated in all her features. Females are believed to be of supreme Shakti. It is alleged that a male devotee to accomplish himself must contemplate himself as a female. He should encounter the emotions of a woman to realize or feel her in an absolute sense. ${ }^{18}$

\section{Kamakhya and Menstruation}

The myopic categorization like pollution, impurity, hot and dangerous are inherently associated with the subject of menstruation. Menstruation blood and a menstruating woman is a taboo in the society which is controlled by strict surveillance and restricted movement. Female bodily construction is viewed as an impure zone during the time of menstruation, and the blood flowed is considered to be dangerous, which has the power to turn anything pure into unclean.

Indic religious literature does not hold an impressive view of menstruation and menstruating women. 'The patriarchal synthesis effected by the Vedic poets involved the construction of a symbolic structure- which glorified women in their role of mothers and simultaneously excluded or mystified and demonised the female biological fluid of blood..$^{19}$ "The Brahmanical law books hold that a menstruating woman must be dreaded and regarded as impure. ${ }^{20}$ 'The image of women projected in the Puranas is far from ennobling. Women are branded as senseless and vile creatures, generally treated as property and condemned to a life of servitude. The Puranas also attach certain taboos. Mantras or the Vedas should not be recited before a menstruating woman. Men are the only legitimate religious specialists. ${ }^{21}$

'Hindu religious writings are varied and can be classified as "early" and "later" texts. The later text of the Manusmiriti presents the most transparent view of menstruation in both particular and general context. Firstly it is said that menstruating women are not permitted to witness Brahmins consuming food. The reason for such a prohibition is plausible because when menstrual blood is shed accidentally into the women's clothing, the Brahmins will simply lose appetite for eating. Still, clearly, there is more involved here that relates to the maintenances of 
caste boundaries separated by taboos and purity.... Secondly and relatedly, menstruation is regarded as unclean within the Hindu tradition and thus purification is necessary for the menstruating women after the last day of her period. Usually, purification is carried out by a bathing ritual which is believed to deal the "impurity" of menstruation. ${ }^{22}$

Tantric tradition, on the other hand, holds an honored understanding regarding the subject of menstruation blood. The theme of blood in the said tradition is observed in two means, one is sacrificial blood, and the other is menstruation blood. It is termed as "Khapushpa" in the tantric tradition. It is presented as an offering to the deity, which is considered to be of divine nature and holds immense power.

Bhattacharyya is of the view that "The deeply ingrained dread of impurity and unholiness and the terror attached to the taboo on menstruating women are not to be found in the primitive and original form of the concept. There are instances especially those of the bleeding goddess in which menstrual blood had developed a sanctifying and purifying influence as a manifestation of the life-giving power inherent in the female sex. This explains why in the Tantras menstrual blood has been regarded as so sacred that it is prescribed as an offering to the great God Shiva and his concert Devi. ${ }^{23} \mathrm{He}$ further argues that 'In the Tantras, menstrual blood is regarded so sacred that it is prescribed as an offering to the great goddess. The menstrual blood of a virgin is the best thing by which the goddess can be pleased. If it is not available, the blood of a married woman or that of a widow will do. ${ }^{24}$ Urban argues that 'Tantra, on the whole, seeks to unleash the tremendous power that is associated with impure substances such as menstrual blood, transforming what is normally a source of pollution into a source of divine energy. ${ }^{25}$

The origin and initiation of annual menstruation festival of goddess Kamakhya termed as Ambubachi Mela cannot be established with certainty. Urban has made an attempt to bring forward the origin of the same as 'The historical origins of Ambuvacı are by no means clear. Probably the earliest reference comes from the Devı Bhagavata Purana (eleventh to twelfth centuries), where it is described as the aftereffect of the intense love-play between Vishnu and the goddess Earth. Assuming his boar (Varaha) incarnation, Vishnu made love to Earth for an entire year of the gods (360 human years). At the end of their dalliance, he worshipped Earth as the supreme goddess. He declared that she would be honoured on several important occasions: at the beginning of the planting season, at the laying of the foundation of a new home, and the end of the Ambuvaci ceremony. ${ }^{26}$

Two varied views could be observed in the symbolic representation of the menstruation festival of Kamakhya in the arguments of Ramos and Urban. Ramos is of the opinion that 'The festival is closely connected with the agricultural cycle. During this time of the year, the water is said to run red with ironoxide, trickling over the yoni in the inner sanctum, so it appears as if the goddess is menstruating. During the festival, a reddened cloth wrapped around the yoni is sought after by pilgrims and prized for its talismanic protective properties. ${ }^{27}$ Urban views it as 'If the goddess gives power and fertility to the world through the blood of her annual menstrual flow, her priests and devotees also return blood to Kamakhya in the form of sacrifice. The primary public form of worship at Kamakhya is now-and probably always has been-animal sacrifice, which to this day is offered several times a day throughout the year, and hundreds of times on holy days.... In sum, the public ritual cycle forms a kind of circuit or cyclical flow of power between Mother Kamakhya and her devotees, embodied in the fluid form of blood. The goddess menstruates annually, giving life to the Earth and blessings to her devotees through her blood; and blood is returned to her through the offering of animal victims, forming a capillary network of power that flows between the deity, the Earth, the priests and her devotees. ${ }^{28}$

The arguments of Ramos and Urban even though are motivating but are of contradictory nature. The symbolic aspect of Menstruation, as argued by Ramos, does not hold appropriate with the argument of Urban. The practice of sacrifice relating with menstruation and blending both the themes of blood together, may not present a comprehensive understanding of the same. Two concerns with the argument could be that it does not represent a symbolic image as a sacrifice in the temple is a living tradition and initiation of both the practices could not be established with certainty and hence could not be said that both shared the same origin. 
The dichotomy of pure- impure and auspiciousinauspicious has been argued by Marglin and Bhattacharyya through alternate understanding. Marglin is of the view that 'Menstrual blood which is highly polluting but at the same time a source of auspiciousness since a woman who does not menstruate is considered very inauspicious. Women are the harbingers of auspiciousness, a state which unlike purity does not speak of status or moral uprightness but of well-being and health or more generally of all that creates, promotes and maintains life. ${ }^{29}$ Bhattacharyya argues that 'Though the menstrual blood is used only in the Tantric cults of the great goddess, the colour of blood and its smearing on cult objects are essential features of all forms of Hindu religious rituals and mode of worship. It, therefore, appears that there developed a spirit of ambivalence in regard to this blood of life. On the one hand, we come across the concept of a menstruating goddess, their supposed blood is regarded as the holiest and efficacious thing and on the other, we also come across a deeply ingrained dread for impurity and unholiness attributed to menstruating women. ${ }^{30}$

The dichotomy of pure menstruation blood of the goddess and impure menstruation blood of a menstruating woman bring forward the inherent patriarchal norm prevalent in the society. The shift in the narration of menstruation blood, bracketing with religion could also be viewed as a futile attempt of patriarchal notion. Amazzone have aptly argued "Menstruation is a potent female experience that patriarchal man has tried to control through religious, cultural and social laws, perhaps because at its essence menstrual blood offers the possibility of reaching a more integrated level of consciousness through the female. ${ }^{31}$

\section{Conclusion}

The bearing of women question in pre- Ahom and Ahom could be narrated in an evident fashion when viewed through the lens of sacred space. Women narration during the said period are not in abundance and are vague. Thus observing it through the lens of sacred space may enhance the possibility to display a visible image-the epigraphical records aids in understanding the same.
Illustration of Kamakhya in the religious milieu of Assam can hardly be overlooked. Tantric tradition being an inherent part of the practices and rituals of the institution highlights its bearing on women question. Tantra as a sect or tradition elevates the role and position of women, placing themes like menstruating blood, sexual union and yoni worship in prominence.

Annual menstruation festival of Kamakhya could be viewed variedly, symbolically or blending the two themes of blood in the tantric tradition, i.e. menstruation blood and sacrificial blood. Yet, its significance should be realized from the broader sense of the term. Celebration of menstruation terminates the myopic categorization of the same as impure and dangerous in the religious literature. The dichotomy of pure- impure and auspicious-inauspicious as argued by Marglin and Bhattacharyya can be referred to in this regard. This dichotomy could benefit in understanding the shift in the narration of menstrual blood from the perspective of patriarchal notion, which attempts to bracket it with religion.

Therefore to conclude, we can understand the phenomenon of menstruation as a connected practice that is intertwined with other practices and these are situated in a cultural matrix. If we were to grasp the festival of menstruation at Kamakhya, it would also mean reading the layers of historical and cultural practices that have clouded the same. When we unpack these practices, it gives us an idea of the earlier times when such practices were on a high pedestal and understood as positive affirmations and hence worshipped. In society, all aspects change and it is the phenomenon of religion that changes last and thus such survivals of a bygone time can be understood in the form of religious practices.

\section{Acknowledgement}

The author wants to thanks Dr. M. N. Rajesh and Dr. Taufeeq Ajaz for their valuable suggestion given while preparing the paper. The author is also grateful to the anonymous reviewers for their comments and suggestions. 


\section{Funding}

The author(s) received no financial support for the research, authorship, and/or publication of this article.

\section{Conflict of Interest}

The authors do not have any conflict of interest.

\section{References}

1. Biernacki, Loriliai 2007, Renowned Goddess of Desire: Women, Sex, and Speech in Tantra, (Oxford University Press, New York), p 182- 183.

2. Gait, Edward 1906, A History of Assam, (Thacker, Spink \& Co. Calcutta) P ii.

3. Baruah, S.L. 1985, A Comprehensive History of Assam, (Munshiram Manoharlal Publishers Pvt. Ltd., New Delhi), p $152 .$.

4. Ibid, p 152.

5. Ibid, $p$ 153- 154.

6. Nath, R. M. Nath 1978, The background of Assamese culture, (Guwahati), p 9.

7. Gogoi, Nitul Kumar 2006, Continuity and Change among the Ahom, (Concept Publishing Company, New Delhi), p 5.

8. Ibid, $\mathrm{p} 1$.

9. Baruah, Nirode 2008, Sanskritization and Detribalization in early Assam: Some Geographical Aspects (Proceedings of the Indian History Congress, Vol. 69, pp 167-179).

10. Chatterjee, Dr. Suniti Kr. (Ed.), 1976, The Cultural Heritage of India, Vol. ii, (The Ramakrishna Mission Institute, Calcutta), p 90.

11. Robinson, William 1975, A Descriptive account of Assam, (reprint) (K.M. Mittal, Sanskaran Prakasan, New Delhi), p 264.

12. Lahiri, Nayanjot 1990, Landholding and Peasantry in the Brahmaputra Valley C. 5th13th Centuries A.D. (Journal of the Economic and Social History of the Orient, Vol. 33, No. 2, Published by BRILL) p161- 162.

13. Dubi Copper plate of Bhaskarvarman, vv. 50,57 .

14. Hayunthul copper plate of Harjaravarman, last line; Tezpur copper plate of Vanamaia, vv. 13, 15.

15. The Gachtal Copper plate grant of Gopalavarman, v. 22.

16. Barua, Hem 1954, The Red River and The Blue Hill, (Lawyers Book Stall, Guwahati), p 3.

17. Sharma, Suresh Kant, Sharma, Usha (ed), 2005, Discovery of North-East India, Vol 5: Assam, Economy, Society and Culture, (Mittal
Publications, New Delhi), p 169.

18. Kakati, Nilam 2017, An Analysis of Vedic and Tantric Tradition with Special Focus on Kalika Purana, (Imperial Journal of Interdisciplinary Research, Vol:3, Issue:4),p 1406.

19. Chawla, Janet 1994, Mythic Origins of Menstrual Taboo in Rig Veda, (Economic and Political Weekly, Vol. 29, No. 43, pp. 2817-2827). P 2862.

20. Bhattacharyya, N. N.1980, Indian Puberty Rites, (Munshiram Manoharlal Publishers Pvt. Ltd. New Delhi), p 13.

21. Rocha, Rosario \& Pandikattu, Kuruvills (Ed.) 2002, Visions and Dreams: New Horizons for an Indian Church: Essays in Honor of Professor Kurien Kunnumpuram, (Jnana Deepa Vidyapeeth, Pune), p 238.

22. Hunt, Stephen J. \& Yip, Andrew K. T. (Ed.) 2016, The Ashgate Research Companion to Contemporary Religion and Sexuality, (Routledge, Taylor \& Francis Group, London), p 214.

23. Bhattacharyya, N.N. 2005, History of the Tantric Religion: An Historical, Ritualistic and Philosophical Study, (Manohar, New Delhi), p 136.

24. Bhattacharyya, N. N. 1980, Indian Puberty Rites, (Munshiram Manoharlal Publishers Pvt. Ltd. New Delhi), p 9.

25. Urban, Hugh B 2009, The Power of Tantra: Religion, Sexuality and the Politics of South Asian Studies, (I.B.Tauris \& Co Ltd. London), p 56.

26. Ibid, p 53-54.

27. Ramos, Imma 2017, Pilgrimage and Politics in Colonial Bengal: The Myth of the Goddess Sati, (Routledge, Taylor \& Francis Group, New York), p 52.

28. Urban, Hugh B 2015, Matrix of Power: Tantra, Kingship, and Sacrifice in the Worship of Mother Goddess Kamakhya, (South Asia: Journal of South Asian Studies, Publisher: Rotledge, 27 July), p 514- 520. 
29. Marglin, Frederique Apffel 1985, Wives of the God- King: The ritual of the Devadasis of Puri (Oxford University Press, Delhi), p 19.

30. Bhattacharyya, N. N. 1980, Indian Puberty Rites, (Munshiram Manoharlal Publishers Pvt.
Ltd. New Delhi), p 18.

31. Amazzone, Laura 2010, Goddess Durga and Sacred Female Power, (Hamilton Books, UK.) p 172. 